\title{
Review Article: Borders, Centres and Peripheries in late Roman and Visigothic Iberia
}

\section{Jamie Wood, University of Lincoln, UK}

Email: jwood@lincoln.ac.uk

Address: School of History and Heritage, University of Lincoln, Brayford Pool, Lincoln, LN6 7TS, U.K.

Tel. No.: $+44(0) 1522837389$

\begin{abstract}
:
This review article surveys scholarship on the evolving provincial organisation of Iberian Peninsula in the late and immediately post-Roman periods (fourth to early eighth centuries CE), when the region moved gradually from the control of the Western Roman Empire to that of the kingdom of the Visigoths, a "barbarian" group who had gradually integrated themselves into the late Roman order in the fourth and fifth centuries. My analysis of this issue over a long time frame suggests that the internal divisions and external boundaries of the late antique Iberian Peninsula (Roman Hispania) were highly fluid and liable to change in response to economic, military, religious and, above all, political factors. The exact make up of Hispania in this period was largely dependent on an ongoing dialogue - sometimes peaceful, sometimes conflictual - between central sources of authority, whether imperial or royal, and more regionally-based powers.
\end{abstract}

\section{Keywords:}

Iberian Peninsula; late antiquity; medieval; provincial organisation; regionalism; Roman Empire; Spain; Visigoths 
This article provides an overview of the historiography on the evolving regional configuration of the Iberian Peninsula of the late Roman and immediately post-Roman (Visigothic) periods, focussing on the long term tensions that existed between central and peripheral sources of authority and identity. Roman and post-Roman administrators struggled to shape the natural and human geography of the Iberian Peninsula to meet the military, bureaucratic or ecclesiastical needs of their organisations. ' Under the Roman Empire and the post-Roman kingdoms, the Iberian Peninsula (usually referred to as Hispania in the contemporary sources) contained a number of smaller administrative and geographical units, some of which were well aligned with ethnic, geo-political and/or economic regions. They were equally likely, however, to be the result of decisions taken at the imperial or royal 'centre', or due to the initiatives of military leaders or local elites at the regional or local levels. The borders of the provinces, and of Hispania as a whole, shifted and often extended over 'natural' land and sea boundaries, notably the Pyrenees and the Straits of Gibraltar. Human economic and political processes had the effect of turning such 'borders' into conduits for various kinds of connection between the societies on either side. So, although the denomination Hispania was commonly used to describe the Iberian Peninsula and some of its constituent parts, the meaning of the term seems to have been very flexible. Its application in administrative practice varied according to context and changed considerably over time, often being modified in the face of ongoing tensions between central and regional elites.

\section{Background: Provinces and regions of Roman Hispania}

Direct Roman intervention in the Iberian Peninsula began in 218 BCE as a a key front in the Second Punic War (218-201 BCE) against Carthage. The outbreak of the war was occasioned by the Carthaginian sack of the city of Saguntum, a Roman ally located on the eastern coast of the Iberian Peninsula.iii Yet Roman diplomatic interest in the Iberian Peninsula extended back further. A treaty was signed with Carthage in 226 BCE which seems to have established the River Ebro as the line dividing the two powers' respective spheres of influence. ${ }^{i v}$ Following victory in the Second Punic War, in 197 BCE the Senate laid the foundations for the future territorial organisaton of the Iberian Peninsula. Two praetors (magistrates with military-administrative functions) were sent there, each with his own provincia, the precise boundaries of which they were to determine for themselves. ${ }^{v}$ This was entirely in keeping with the use of the term provincia in the early phases on Roman imperialism, when it designated the sphere of action of a Roman magistrate, not a clearly-defined geographical area. ${ }^{\text {vi }}$ 
Over time, there was a shift from a functional to a territorial sphere of action as the two provinciae were soon clearly differentiated from one another along geographical lines. This was the result of the military commanders taking on a range of 'civil' activities, such as tax-gathering and legal roles, as well as the foundation of Roman and native settlements. ${ }^{\text {vii }}$ The new territories of Hispania Citerior and Hispania Ulterior, established in the early second century BCE, were centred on the cities of Tarragona and Córdoba and named according to their distance from Rome ('nearer' and 'further' Spain respectively). These provinces controlled the eastern and southern littorals respectively as Roman military power did not extend to the west and north until later in the first century, and even then did so only gradually. ${ }^{\text {viii }}$ The division of the parts of the Iberian Peninsula that were controlled by Rome into two provinces named Hispania seems to have been responsible for the tendency of many of our sources - present but not always prevalent - to use the plural Hispaniae ("Spains") rather than the singular Hispania when referring to the Peninsula.

Under Augustus (d. 14 CE) the long drawn out conquest of Spain was finally completed and this was accompanied by a reorganisation of the provincial structure that recognised the differential geographical and ethnic makeup of the Spanish regions, the extent to which the regions had adopted Roman culture and integrated into the imperial system, and the need to station troops at strategic points. ${ }^{i x}$ As with the earlier stages of Roman intervention in the peninsula, the activities of military commanders on the ground played more important roles than any kind of centralised and systematic planning in the development of the provincial administration. ${ }^{x}$ Hispania Ulterior was divided into two provinces, Baetica and Lusitania, with capitals at Córdoba and Mérida respectively. ${ }^{\mathrm{xi}}$ The emperor retained control of Lusitania, which at first also included Gallaecia in the north west of the peninsula. ${ }^{\text {ii }}$ Hispania Citerior, by far the largest province, was soon augmented by the transfer of Gallaecia to its purview. ${ }^{\text {xiii }}$ The enlarged Citerior came to be known as Tarraconensis after its capital, Tarragona.

Under Augustus, the provinces were additionally broken down into units known as conventus. ${ }^{\text {xiv }}$ Originally an unofficial designation for an association of Roman citizens, generally located in larger towns, under Augustus the conventus took on a formal administrative role that was mainly judicial. It no longer referred to an association, but to a "geographic region comprising many lesser towns", the inhabitants of which would travel to the main town (conventual capital) to engage in lawsuits. ${ }^{\mathrm{xv}}$ 
Such towns also fulfilled important commercial, administrative and religious functions as central sites within their regions and over time they came to operate as foci for civic identities that facilitated interaction with the imperial power. ${ }^{\text {xvi }}$

The conquest of Hispania was gradual and different parts of the Iberian Peninsula had engaged with the Mediterranean socio-economic world for varying periods of time. The consequence of this was that the regions experienced the effects of Roman influence at varying rates. Broadly speaking, the south and east were characterised by more city-based political and economic organisation and were more fully-integrated into Mediterranean economic and cultural networks. ${ }^{\text {xvii }}$ Such regions were therefore more rapidly integrated into the Roman Empire at an earlier date. By contrast, more central and northern parts of Spain had less in common with existing Roman social and political systems and were thus more difficult to reconcile to Roman rule and to incorporate into the empire after the conquest. ${ }^{\text {xviii }}$ Scholars have established that the relationship between pre-Roman and Roman cultural, economic and social practices was by no means uniform within and between these regions. Ongoing, complex and multi-dimensional dialogues and exchanges existed between the local and the imperial levels in Spain, as elsewhere across the empire. ${ }^{\text {xix }}$ In the first and second centuries CE the southern region of Baetica, in particular, benefitted from its role as primary supplier of oil to Rome itself and to the military on the northern frontiers. State subsidies for the transport of these materials also benefitted other parts of the regional economy. ${ }^{\mathrm{xx}}$ By the second and third centuries CE, it would be fair to say that most of Spain was securely integrated into the imperial system. ${ }^{x x i}$

In summary, the drawn out nature of the Roman conquest of Iberia and the peninsula's varied human and physical geography undoubtedly shaped the provincial boundaries of Roman Hispania. However, equally important were the decisions that were taken at higher levels about the military and administrative organisation of the peninsula. Especially significant was Hispania's relationship with other parts of the empire such as the frontier garrisons.

\section{The provinces and regions of late Roman Spain}

The administrative organisation of Spain remained largely as it had under Augustus until the late third century CE. In the Tetrarchic system devised by the Emperor Diocletian (r. 284-305; d. 316), the empire was ruled by two senior emperors (Augusti) and two junior emperors, known as Caesars. 
Each of these four emperors ruled a small number of dioceses which were in turn divided into a number of provinces. These provinces were often considerably smaller than those that had preceded them. In this system, the newly-created diocese of Spain was combined with Britain and Gaul under the rule of the Caesar Constantius I Chlorus, while Maximian retained Italy and Africa in the senior position as Augustus in the West. ${ }^{\text {xii }}$ Although the Augustan provinces of Baetica and Lusitania were maintained, the massive province of Hispania Citerior was broken up into Tarraconensis (capital Tarragona), Carthaginiensis (capital Cartagena, incorporating coastal areas southwest of Tarragona, extensive inland territories and the Balearic Islands), and Gallaecia in the northwest (capital Braga). The new Spanish diocese was completed by the addition of Mauretania Tingitania, a stretch of land across the Straits of Gibraltar in modern-day Morocco. Some of Diocletian's reforms seem to have drawn on precedents set earlier in the third century, although it is not clear when exactly these were enacted. ${ }^{x i i i}$ The new diocese of Spain had definitely been created by 298 when the vicarius of the diocese, Aurelius Agricolanus, appears at Tangiers (ancient Tingi), in Mauretania Tingitania. ${ }^{\text {xiv }}$ In the Laterculus Veronensis (Verona List) of 314, which lists the administrative units that made up the empire, the Spanish diocese (Hispaniae: "the Spains") is comprised of the six provinces of Baetica; Lusitania; Carthaginiensis; Gallaecia; Tarraconensis; Mauretania Tingitana. ${ }^{x \times v}$

Kulikowski has suggested that the Diocletianic reorganisation of Hispania was designed to provide the westernmost part of the African frontier with a hinterland from which it could draw resources, in much the same way as the Gallic provinces supplied troops on the Rhine frontier. A strong frontier would forestall potential incursions into Hispania from Africa, such as those made by Mauretanian tribes during the reign of Marcus Aurelius (r. 161-180). ${ }^{x \times v i}$ In addition to this strategic realignment, the Tetrarchic reforms recognised the long-standing connections that existed between the country and the westernmost parts of northern Africa. Throughout antiquity there had been a large amount of economic, political and military contact across the Straits of Gibraltar, which consistently performed a connective rather than a divisive function. There was thus no 'frontier' between Hispania and Africa and under the Tetrarchs the interconnection of these two regions was formalised administratively. ${ }^{\text {xxii }}$ The Tetrachic reorganisation of the administrative structures of Hispania thus recognised the economic and cultural realities of ongoing and substantial contacts between the Iberian Peninsula and northern Africa. This episode also demonstrates that, as under the Republic and early empire, the organisation and boundaries of the Spanish provinces were 
often dependent on the decisions of the government. As we shall see in what follows, socioeconomic linkages across the Straits of Gibraltar endured long after the Western Roman Empire had lost control of Hispania and the connective nature of the Straits pushed elites on both sides to try to extend their power to the other side.

In the late fourth century Spaniards played a key role at the centre of imperial politics. Theodosius I (r. 379-395) became Eastern Roman Emperor in the aftermath of the defeat and death of the Emperor Valens at the battle of Adrianople in 378. Theodosius' rise to power in Constantinople and his later take-over of the Western Empire was accompanied by the rise within the upper echelons of the imperial hierarchy of a number of other Spaniards who played key roles in the imposition of Nicene orthodox Christianity and outlawing of paganism within the empire. Scholars used to interpret Theodosius' takeover as a victory for a particular Spanish brand of orthodox Christianity, but Neil McLynn has recently questioned the extent to which these individuals were "Spanish" by geographical origin, or acted as a "Spanish" "party" that put forward a consistent policies in terms of politics or religion. ${ }^{\text {xxviii }}$ The fact that large parts of Hispania fell so rapidly out of Roman control after the reign of Theodosius should perhaps alert us to the fact that its integration into the empire depended to a large extent on the robustness of the overall system. ${ }^{\text {xix }}$

\section{The provinces and regions of Post-Roman Spain}

From 409 CE, when various "barbarian" groups who had recently crossed the Rhine at the end of $406 \mathrm{CE}$, crossed the Pyrenees, Roman power in Hispania waned rather quickly. ${ }^{\mathrm{xx}}$ The government did make efforts to exert its influence in the peninsula through the use of allied Visigothic troops and sometimes by intervening directly. ${ }^{x x i}$ The empire seems to have maintained effective control in Tarraconensis and parts of Carthaginiensis until around $460 .{ }^{x x i i}$ Yet despite the breakdown of central Roman authority in Spain, there seems to have been a remarkable degree of continuity in the provincial organisation. Recent work has demonstrated that in post Roman Spain previous systems of administration and power endured at local and regional levels for some time. ${ }^{\text {xxiii }}$ The central Roman administration could no longer assert its power in Spain by the middle of the fifth century, yet the structures that it had imposed on the country lived on and served as foci for local administration and identities for much longer. The elites of post-Roman Spain continued to use the provincial vocabulary of the empire, using it to serve their own ends rather than the aims of the imperial centre. 
Our most important written source for this period is the Chronicle of Bishop Hydatius of Lemica (d. late fifth century), which covers the years $378-468$ and is particularly useful for the information it provides on the breakdown of Roman power in Spain in the mid fifth century. ${ }^{\text {xxiv }}$ Hydatius' work is particularly important for two reasons. First, it demonstrates the narrowing of horizons in Spain as the era of Roman imperial control receded from memory. This is because, despite efforts to the contrary, Hydatius was unable to access much information about events outside of his native Gallaecia. His Chronicle therefore focuses largely on his home province, with only occasional insights into events further afield. ${ }^{x x v}$ Second, the work provides excellent evidence for the emergence of local "self-help" groups as individual cities and territories sought to achieve security in the face of the breakdown of the Roman military infrastructure in Spain. Following the intervention of barbarians in Gallaecia, particularly the Sueves, Hydatius took on a role as representative and negotiator for his city and province with what was left of the imperial administration and the barbarians. ${ }^{x \times x v i}$ Local leaders, especially bishops, took on greater responsibility in this time of upheaval as they sought security for their communities, replicating processes that were occurring all across the late antique Mediterranean. ${ }^{\text {xxvii }}$ Hydatius thus demonstrates the gradually narrowing horizons of post-Roman Spain onto a regional and provincial level.

However, Hydatius' Chronicle also illustrates that the continuing vitality of the late Roman provincial vocabulary, if not the administrative machinery. By the end of the fifth century the boundaries of the Suevic kingdom largely conformed to those of the Roman province of Gallaecia. ${ }^{\text {xxviii }}$ Neither Hydatius' information network nor the new politically-dominant force extended far beyond the boundaries of Gallaecia and even his account of the method by which the different barbarian group divided Hispania up between themselves at the beginning of the fifth century suggests that the Roman provinces were still considered to be the basic building blocks of the Iberian Peninsula was divided:

When the provinces of Spain had been laid waste by the destructive progress of the disasters just described, the Lord in his compassion turned the barbarians to the establishment of peace. They then apportioned to themselves by lot areas of the provinces for settlement: the Vandals took possession of Gallaecia and the Sueves that part of the 
Gallaecia which is situated on the very western edge of the Ocean. The Alans were allotted the provinces of Lusitania and Carthaginiensis, and the Siling Vandal Baetica. ${ }^{\text {xxix }}$

The kingdom that the Sueves established in Gallaecia in the north-west was to survive until the expansionist activities of the Visigothic King Leovigild in the mid-580s and, at times, they expanded their power to the south and east. ${ }^{\mathrm{xl}}$ From the later fifth century, therefore, political life gradually regionalised as local elites and barbarians competed for control across the Iberian Peninsula. For all except the first decade of the fifth century it is very hard to speak of Hispania as a unified political or administrative entity, although elements of the Roman infrastructure and administrative vocabulary continued to function.

\section{Connections across the Pyrenees and the Straits of Gibraltar}

Just as there were long-standing contacts between southern Iberia and northern Africa across the Straits of Gibraltar, so in the north the Pyrenees functioned more as a conduit than as a barrier to connectivity throughout the Roman and post-Roman periods. These contacts, which have been traced in the onomastic and toponymic registers, as well as in archaeological, architectural and numismatic evidence, were increased due to the integrative effect of the Roman imperial system. ${ }^{x \mid}$ The material record for the late and post Roman periods demonstrates continued connectivity across the Pyrenees. ${ }^{x l i}$ The emergence of Christianity as the religion of empire during the fourth century occasioned further interactions between the supposedly separate provinces of Gaul and Hispania, with bishops from the latter participating at the Council of Arles in 314 and Gallic bishops attending the Council of Zaragoza in 380. ${ }^{\text {xliii }}$ The so-called Priscillianist controversy, which may have precipitated the council at Zaragoza, also demonstrates connections between the provinces to the north and south of the Pyrenees. Priscillian was a charismatic aristocratic Christian from northern Spain whose practices drew the opprobrium of a number of Spanish bishops. Although he had some episcopal support within Spain and was elected as a bishop himself, he was eventually executed on the charge of sorcery by the government of Magnus Maximus (r. 383-388) at some point between 385 and 387. The key point here is that both Spanish and Gallic bishops intervened for and against Priscillian, while he seems to have drawn considerable support from a number of Gallic nobles, some of whom were punished alongside him. ${ }^{\text {liv }}$ Informal aristocratic and ecclesiastical connections thus subverted the supposed boundaries separating the provinces of Gaul and Hispania. 
The movement of various barbarian groups into Hispania in 409 CE led the western Roman government to utilise another barbarian group, the Visigoths, as foederati (federate troops) as part of efforts to retake control of the Peninsula. In 418 the Visigoths were settled in the province of Aquitania Secunda in southern Gaul and continued, at least at first, to act largely in pursuance of imperial interests within Hispania while extending their power base in southern Gaul. ${ }^{\text {xlv }}$ The gradual diminution of Roman power in Hispania over the remainder of the fifth century was accompanied by increasingly independent action by the Visigoths. The Visigothic kingdom thus extended its control over much of southern Gaul and into parts of northern Iberia. Further impetus to expansion in Iberia came in 507 when the Gallic holdings were seriously reduced by the Franks who, under King Clovis (d. 511), defeated the Visigoths and killed their king at the Battle of Vouillé. The Visigothic kingdom was saved from total destruction by the intervention of the Ostrogoths under Theoderic the Great (d. 526). From the early sixth century, therefore, the remnants of Visigothiccontrolled Gaul and Hispania became part of a greater Ostrogothic polity centred on Italy.

We should not imagine that the Visigoths were in complete control of Hispania either before or after the disaster at Vouillé. The Sueves held Gallaecia, while much of the rest of the Peninsula was under the authority of regional and city-based powers. Córdoba, for example, the former capital of the province of Baetica, remained independent of Visigothic authority until the reign of Leovigild ( $r$. 569-586) and inflicted an embarrassing defeat on the army of one of his predecessors, Agila (r. 549554). ${ }^{\text {xlvi }}$ Although there are reports of kings and their forces in cities across the peninsula during the first half of the sixth century, this does not constitute definitive proof of permanent Visigothic control. The conquest of Hispania was a drawn-out process and not completed until the final quarter of the century. ${ }^{\text {xlvii }}$

During this period the long-established connections between southern Hispania and northern Africa continued. As we have already seen, economic, political and military contact across the Straits of Gibraltar had been common throughout antiquity. ${ }^{\text {xlviii }}$ These contacts continued as the Visigoths extended their control over Hispania in the course of the sixth century. Gelimer (r. 530-534), the Vandal king, solicited aid from the Visigoths in a conflict with the Eastern Roman in 534, and there were instances of direct Visigothic action in North Africa. ${ }^{x \text { lix }}$ For example, the attempt of King Theudis (r. 531-548) to take Septem (modern Ceuta) from East Roman forces in 548 ended in a disastrous defeat.' 
The Eastern Roman Empire had not given up hope of regaining control of the western provinces and this was to lead to further interaction across the Straits. From the mid-530s to the mid-550s Justinian (d. 565), the Eastern Roman Emperor, sent a series of expeditions to Africa, Italy and Spain in order to conquer the provinces from the "barbarians" who had set up kingdoms in the late fifth and early sixth centuries. After the successful conquest of Vandal Africa in 534, East Roman forces moved quickly to occupy Septem in North Africa, where a garrison and naval force were stationed. The Balearic Islands were soon taken too. The forces at Septem were responsible for monitoring events in Spain and Gaul, securing Africa from possible attack by the Visigoths, establishing control of the Straits, and laying the foundations for any potential offensive against southern Spain. ${ }^{\text {li }}$ In 552 this possibility was realised when an expeditionary force was sent to southern Hispania in response to an appeal for aid from Athanagild (d. 567), a Visigothic usurper who later became king. The Romans were unable to conquer much more than a strip of coast (with some adjoining territory inland) between Cartagena and Málaga, although the province, known as Spania, was not taken by the Visigoths until the 620s. ${ }^{\text {lii }}$ It is likely that Spania was under the jurisdiction of the African exarchate. ${ }^{\text {liii }}$ The small distance that separated Hispania from Africa meant that any power wishing to secure their possessions on one side was almost inevitably drawn to intervene on the other: the seaways thus seems to have functioned as a driver for military as well as economic connection, rather than division.

There has been considerable debate in recent years between proponents of an organised frontier between Spania and the territory that was under Visigothic control. ${ }^{\text {liv }}$ It is likely that this debate cannot be resolved satisfactorily because of the fragmentary nature of our evidence base: there are few written sources and interpretations of the archaeological record, which is extensive, are insufficiently refined at present to permit the kind of definitive statements about the ascription of sites to one side or another. ${ }^{\text {Iv }}$ It is therefore very difficult to identify which areas were under Visigothic and Eastern Roman control, when ownership shifted and how different sites related to one another. ${ }^{\text {Ivi }}$ It may well be that Martin's conceptualisation of the frontier as a territorial zone, rather than a linear construction, is perhaps the best way forward, given the current state of knowledge. ${ }^{\text {Ivii }}$ 
Whatever the administrative status of the province of Spania and the exact nature of the relationship between Visigothic and Eastern Roman territories, material evidence suggests that there was considerable interaction across the "border". "viii Despite ongoing contacts, the fact that Spania was connected politically and administratively to Africa meant that far more intensive contacts took place between the province, especially its capital Cartagena, and Africa, particularly its capital of Carthage. ${ }^{\text {lix }}$ The area of south-eastern Spain that was conquered by Eastern Roman forces was thus as integrated administratively and economically with Africa as it was with the rest of the Iberian Peninsula, acting as a conduit for the exchange of goods, people and ideas into the Visigothic kingdom.

The Visigothic kingdom thus straddled both sides of the Pyrenees, and at times the kings seem to have recognised that it was in their strategic interests to cultivate their influence across the Straits into northern Africa. Their power in the Iberian Peninsula was by no means total. They had to compete with a range of local, regional and international powers. The assertion of Visigothic control over the entire peninsula was a drawn-out affair, lasting almost two hundred years and, as we shall see in the next section, the extent of the Visigoths' hold over Spain was variable as regional and local groups often asserted their independence from the authority of the royal and ecclesiastical centre at Toledo.

\section{The regionalisation of Visigothic Spain}

Recent archaeological work has suggested that gradual evolution best characterises the transition from the Roman to the Visigothic period in the Iberian Peninsula. ${ }^{\mathrm{x}}$ Although the general trend seems to have been towards reduced economic activity and diversity, the pace of change was neither rapid nor uniform across the peninsula. ${ }^{\text {Ixi }}$ Regions with a stronger tradition of alignment with Mediterranean economic systems were harder hit by the changing order, with the previouslydiscussed exception of the Byzantine province of Spania, which meant that the south-east of the peninsula was able to maintain contacts with Africa in particular well into the seventh century. . $^{\text {ii }}$ Rural settlement patterns point towards the gradual development of more restricted and regionally-based socio-economic elites than had been the case in the late Roman period. ${ }^{\text {Iiii }}$ This process was accompanied by the development of more regional identities across the peninsula, as we have already see, and the Visigothic kings campaigned repeatedly against northern groups such as the Basques and the Cantabrians during the sixth and seventh centuries. Ixiv 
It was not until the last quarter of the sixth century that anything approaching pan-Iberian political unity was attained again. The Visigoths moved slowly from being just one of many competing political powers within the peninsula to a position of dominance. By campaigning throughout Spain, King Leovigild (r. 569-586) brought many local powers under his dominance, building cities in order to solidify his control over recently-conquered regions and to symbolise his power. ${ }^{\mid x v}$ The conquest was accompanied by the refinement of a range of offices and bureaucratic processes that seem to have been designed to tie regional elites more firmly into the political centre at Toledo. ${ }^{\text {Ixvi }}$ Partly this worked by giving them access to office, and partly by passing laws that reinforced their power in the provinces. ${ }^{\text {Ixvii }}$ In the realm of ideology, we see the projection of an image of political and religious unity and loyalty from the centre across a range of legal, historical and ecclesiastical sources. Often this was accompanied by hostility to more regionally-based forms of authority and belonging. ${ }^{\text {Ixviii }}$

Leovigild's attempts to extend Visigothic power did not go unopposed, in north and south. He seems to have granted one of his sons, Hermenegild, a significant degree of autonomy in southern Spain, establishing him in Seville, probably to reinforce the Visigoths' western flank against Spania. Hermenegild raised a revolt against his father in $\mathbf{5 8 0}$ that was centred on the cities of the south. There is much debate about whether a significant proportion of the local population joined with the Visigothic rebels, although there is little doubt that some of the cities of the south, such as Córdoba, had long been resistant to attempts by the Visigothic kings to establish their hegemony. ${ }^{\text {|xix }}$ Mark Handley has additionally suggested that dating formulae on inscriptions may have functioned as markers of regional identity in southern and south-western Spain from the mid-fifth to the midsixth-centuries. ${ }^{1 \times x}$ At some point Hermenegild converted to Nicene Christianity, possibly in an attempt to gain support from the Hispano-Roman population of the region, the majority of which was also Nicene. ${ }^{\mathrm{lxxi}}$ We do not know whether this move had the desired effect or was a last act of desperation. In any case, it took time for Leovigild to turn his attention to Hermenegild, possibly because he needed to extricate himself from campaigns elsewhere in Spain. After eliminating his rebellious son, he continued his expansionary activities, finally subduing the Suevic kingdom in 585, confirming the Visigothic monarchy as the dominant power in Spain, although as noted above, the Byzantine province of Spania was not suppressed until the 620 s. 
By the 630s the Iberian Peninsula was unified under a single political power for the first time since the beginning of the fifth century. Scholars used to consider this a singular moment of unity between state and church, the prototype for all subsequent centralising regimes from the Catholic Monarchs to the Franco dictatorship. ${ }^{\text {Ixxii }}$ However, as we have already seen, kings struggled throughout the seventh century to establish their power in the face of intermittent opposition from the nobility in the provinces. ${ }^{\mid x i i i}$ The most notable example is the rebellion of the dux Paul in Narbonnensis (the province of Visigothic-controlled southern Gaul) in the 680s, although there were several other instances of outright rebellion in the provinces. ${ }^{\text {Ixxiv }}$ There were continuing contacts across the Straits of Gibraltar, culminating the in Arab-Muslim invasion of 711, which led quickly to the downfall of the Visigothic kingdom. ${ }^{\text {Ixxv }}$

\section{The ecclesiastical organisation of Visigothic Spain}

Analysis of the ecclesiastical structure of Iberia under the Visigoths further reveals the 'patchwork' nature of the country's provincial organisation and the dependency of boundaries on developing political power structures. A few examples suffice to demonstrate the point. The Nicene Church seems to have been organised into provinces that broadly coincided with those of the Tetrarchic diocese of Spain, although with some modifications. ${ }^{\text {Ixvi }}$ There were efforts to establish overarching ecclesiastical authorities, such as when the bishop of Seville was made vicar of the entirety of Spain by the papacy in 469/483, a role which in 521 was split with the bishop of Elche. This may have in part been the result of the papacy's recognition that in order to make its authority felt in Spain it was better to devolve responsibility to a local power than to attempt to assert itself from Rome. ${ }^{\text {Ixvii }}$

The bishoprics of Visigothic-controlled southern Gaul were integrated into the ecclesiastical hierarchy of the Visigothic kingdom and took part in 'national' church councils in Toledo, after the conversion of the Visigoths to Nicene Christianity in 589. Church councils for the province of Narbonnensis took place in the city of Narbonne, bringing together the bishops of the southernmost parts of Gaul, in a similar way as they did in the ecclesiastical provinces in Hispania. Ixxviii Political boundaries thus conditioned the functioning of the ecclesiastical infrastructure of the Visigothic territories of Gaul and Hispania.

The impression of the conditioning effect that politics had on religious organisation is both reinforced by the processes of consolidating Visigothic power in Iberia in the late sixth and early 
seventh centuries. The creation of the ecclesiastical province of Carpetania in the early seventh century, which was formed out of those parts of Carthaginiensis which were not under Eastern Roman control, was due to the desire of the political and ecclesiastical elite on the Visigothic side of the border to boost the status of Toledo, which became capital of the new province and was to remain so after the conquest of the old provincial capital, Cartagena, in the mid-620s. ${ }^{\text {Ixxix }}$ When the Suevic kingdom and Spania were conquered in the late sixth and early seventh centuries respectively, the bishoprics in those regions were reintegrated into the ecclesiastical provincial structure of Visigothic-controlled Iberia and church councils were held to try to smooth the reintegration process. ${ }^{\mathrm{Ixx}}$ For example, when Spania was dismantled, bishoprics that had formerly been part of Baetica were integrated into the church structure there, while those that had been part of Carthaginiensis rejoined the provincial apparatus there. Those bishoprics which had been partitioned between Byzantine and Visigothic territories were also reconstituted according to their previous boundaries, a principle which was affirmed at the Second Council of Seville in 619. ${ }^{\text {Ixxi }}$ So, although the provincial organisation of the Church in Hispania was dependent on the exigencies of the political situation, the ecclesiastical authorities sought to realign the bishoprics into preestablished configurations as soon as they had the opportunity to do so. This process was driven by the interests of the metropolitan bishops who had precedence within the overall province and individual bishops at the level of their diocese, both groups of which had an interest in maximising the scope of their responsibilities and were willing to enter into legal disputes in order to establish their ancient prerogatives.

It is also noteworthy that many of the centralisers among the Visigothic elite had a somewhat ambiguous attitude towards the provinces of Gallaecia and Narbonnensis. The fact that the Visigothic kingdom used to be centred on Toulouse, in southern Gaul, and the coterminous relationship between the kingdom of the Sueves and provincial boundaries of Gallaecia led some authors to present them positively as sub-kingdoms within what might be described as an overarching Visigothic commonwealth. ${ }^{\text {Ixxii }}$ For other writers, however, the independent history of these territories roused suspicion about their loyalty to Visigothic overlord-ship. ${ }^{\text {Ixxiii }}$ In the case of Narbonnensis, a region that seems to have developed a distinctive identity within the Visigothic kingdom, this suspicion was quite often realised, with notable rebellions taking place periodically in the late sixth and seventh centuries. ${ }^{\text {Ixxiv }}$ The role of the province as a frontier zone between the Visigothic and Frankish kingdoms, the latter of which maintained a consistent claim to the territory, 
seems to have encouraged this tendency. ${ }^{\operatorname{lxx} v}$ Notable examples are a rebellion against Reccared in 588 and the secessionist revolt of the $d u x$ Paulus against Wamba (r. 672-680) in 673 CE, the latter of which seems to have aimed to establish a separate kingdom centred on Narbonne. ${ }^{\text {Ixxvi }}$ Frank Reiss has suggested that the latter of these revolts demonstrates the development of a unique Narbonnese identity, possibly paralleled by an increasing sense of association with the Franks to the north, which operated in tension with the centralising tendencies of the Visigothic royal government in Toledo. It has recently been argued that during this period the province of Tarraconensis, especially those parts of it which lay in the Pyrenees, contained a clearly-articulated frontier system, although this is by no means widely accepted yet. ${ }^{\text {Ixxvii }}$ It also seems likely that with the fall of the Visigothic kingdom in 711 a short-lived trans-Pyrenean kingdom was established in the north-eastern provinces of Narbonnensis and Tarraconensis. ${ }^{\text {Ixxxviii }}$ Right at the very end of the kingdom, therefore, just as throughout Spanish late antiquity, the Pyrenean mountain range served a connective rather than a divisive function.

Earlier in this essay I posited that the Visigothic conquest of Iberia (and a part of southern Gaul) was neither rapid nor unopposed. Similarly, the consolidation of Visigothic power across the Peninsula (and beyond) was not straighfroward. Much recent research has focussed on the tension between the Visigothic royal and ecclesiastical elite, which together had an interest in securing and promoting the unity of Spain, and local elites, who sometimes bought into the centralisers' vision yet on other occasions resisted it. Royal and Church laws were designed to demonstrate the symbolic power of the king and bishops and some of their specific regulations do seem to have included practical measures for tying together civil and ecclesiastical government in the provinces. ${ }^{\text {Ixxix }}$ Other policies and practices, such as laws which reinforced the power of local elites over their dependents, served the purposes of the provincial aristocracy and gave them a reason to buy into the central system. ${ }^{\mathrm{xc}}$

The conversion of the Visigoths from Arian to Nicene Christianity under King Reccared in 587-589 was a turning point. In the late sixth and early seventh centuries, the Visigoths were rebranded gradually by Hispano-Roman Nicene bishops from heretical barbarian invaders to a Catholic Nicene people who were "Roman" in all but name. One of the key selling points of the Visigoths for bishops such as Isidore of Seville was their ability to maintain the unity of Spain, to fight against the regionalist tendencies of provincial elites and to hold the country together. These bishops therefore 
consistently promoted the idea of a unified Spanish-Visigothic-Catholic identity against more localised modes of belonging. ${ }^{x i}$ However, such centralising tendencies existed in constant tension with regional identities, sometimes articulated through texts, on other occasions visible in the material record, and in others manifested by direct actions that suggest a desire for separation - or in the very least autonomy - from the royal centre at Toledo. The strident promotion of the Visigothic monarchy by the Spanish Nicene Church was thus the result of its very shaky foundations on the ground in the provinces. Power and identities had to be projected outwards and always to be negotiated with the provincial elites in Visigothic Hispania and southern Gaul.

\section{Conclusion}

In late antiquity there was not one Hispania, but many. Partly, this was the result of the changing political landscape as the Iberian Peninsula slipped out of the control of the Roman Empire and into that of the Visigothic kings, with regional identities asserting themselves when central power was at its least effective. This article has suggested that it would be a mistake, however, to too closely chart a uni-linear breakdown from centralised Roman 'order' to post-Roman regionalisation. The strength of the Roman system in Hispania lay in its ability to adapt in order to meet the military and bureaucratic needs of the state, at the same time recognising that the social and economic boundaries of the province did not necessarily conform to the peninsula's physical geography. Roman hegemony across the western Mediterranean meant that such flexibility was possible and the successful 'romanisation' of Spain and other provinces was due to the creative interaction of conqueror and the conquered rather than the imposition of imperial culture in the provinces. Put simply, local elites bought into the Roman system because they could get something out of it. ${ }^{\text {xii }}$ The Visigothic kings, on the other hand, were faced with a series of external threats at the same time as seeking to respond to, and in some cases to contain, the power of provincial nobilities. Despite these challenges, the "Spains" of the Visigothic period were as flexible as those of the Romans: their boundaries were consistently redrawn by political and ecclesiastical elites in response to the political and economic geography of the Iberian Peninsula, and in particular to its close and ongoing integration with the neighbouring regions of northern Africa and southern Gaul.

\footnotetext{
'Leonard Curchin, Roman Spain: Conquest and Assimilation (London: BCA, 1991), 10-15.

ii J. S. Richardson, Hispaniae: Spain and the Development of Roman Imperialism, 218-82 BC (Cambridge: Cambridge University Press, 2004).

iii On the 'alliance' with Saguntum, see Richardson, Hispaniae, 20-30.
} 
${ }^{\text {iv }}$ Richardson, Hispaniae, 20-30.

` Michael Kulikowski, Late Roman Spain and Its Cities (Baltimore: Johns Hopkins University Press, 2004), 3, 319.

vi For the development of the term's meaning, see: Andrew Lintott, "What was the Imperium Romanum'?", Greece and Rome second series 28 (1983): 53-67.

vii That the organisation of Roman Spain was done on the initiatives of commanders in the field is one of the central arguments of Richardson, Hispaniae.

viii Curchin, Roman Spain, 57.

ix Patrick Le Roux, “Regards augustéens sur les Gaules et la Péninsule Ibérique ou le recit d'une construction provinciale", in Hispania et Gallia: Dos provincias del occidente romano, ed. Lluís Pons Pujol (Barcelona: Publicacions Universitat de Barcelona, 2010), 33-47 for an overview of administrative and geographical factors that underpinned the Augustan provincial reorganisation.

“ Pablo Ozcáriz Gil, "The 'dioceses' of Hispania citerior in the High Empire. A historiographic invention", Studia Humaniora Tartuensia 12 (2011): 1-18.

${ }^{x i}$ Kulikowski, Late Roman Spain, 5-6.

${ }^{x i i}$ Haley, Baetica felix, 33-37 for discussion of the exact date of the creation of the province.

xiii Curchin, Roman Spain, 57 suggests that this was done for military convenience.

${ }^{\text {xiv }}$ Curchin, Roman Spain, 57-58, 114-123.

${ }^{x v}$ Curchin, Roman Spain, 58.

xvi Bertrand Goffaux, "Priests, conventus and provincial organisation in Hispania Citerior", in Priests and State in the Roman World, eds. James H. Richardson and Federico Santangelo (Stuttgart: Franz Steiner Verlag, 2011), pp. 445-469. xvii S. Keay, Roman Spain (London: British Museum, 1988); Paul Reynolds, Hispania and the Roman Mediterranean, AD 100-700: Ceramics and Trade (London: Duckworth, 2010).

xviii Gregorio Carrasco Serrano, La romanización en el territorio de Castilla-La Mancha (Cuenca, Ediciones de la Universidad de Castilla-La Mancha, 2008); Leonard Curchin, The Romanization of central Spain: complexity, diversity and change in a provincial hinterland (London: Routledge, 2003).

${ }^{\text {xix }}$ Curchin, Romanization. E.g. on the organisation of the landscape, see: Isaías Arrayás Morales, Morfología histórica del territorio de Tarraco (ss. III-I A.C.) (Barcelona, Publicacions Universitat de Barcelona, 2005); on the evolution of urbanism, see: Gregorio Carrasco Serrano, La cuidad romana en Castilla-La Mancha (Cuenca, Ediciones de la Universidad de Castilla-La Mancha, 2012); A. T. Fear, Rome and Baetica: urbanization in southern Spain, C. 50 BC-AD 150 (Oxford: Clarendon, 1996); on economic interactions, see: José Remesal Rodríguez, La Bética en el concierto del Imperio romano (Madrid, Real Academia de la Historia, 2011); Haley, Baetica felix.

${ }^{x x}$ Reynolds, Hispania, 137.

${ }^{x x i}$ However, industries, such as Baetican oil, proved vulnerable when government subsidies shifted to Tunisian producers as early as the late-second-century, Reynolds, Hispania, 10-55.

xxii T. D. Barnes, The new empire of Diocletian and Constantine (Cambridge, MA: Harvard University Press, 1982)

xxiii Kulikowski, Late Roman Spain, 71-72.

xxiv For critical edition, see: Passio s. Marcelli Tingitani, ed. Hippolyte Delehaye, "Les Actes de S. Marcel le Centurion", Analecta Bollandiana 41 (1923): 257-288; Baudouin De Gaiffier, "A propos de S. Marcel le Centurion", Archivos Leoneses 23 (1969): 13-24; for summary and bibliography see: Candida R. Moss, The Other Christs: Imitating Jesus in Ancient Christian Ideologies of Martyrdom (Oxford: Oxford University Press, 2010), 190.

${ }^{x x v}$ For critical edition, see Barnes, The new empire, 201-208

xxvi Javier Arce, "Inestabilidad politica en Hispania durante el siglo II d.C.", Archivo español de arqueología 54 (1981): 101-115. 
xxvii Javier Arce, El último siglo de la España romana: 284-409 (Madrid: Alianza, 1982), 31-62; Kulikowski, Late Roman Spain, 71-76 for general contacts.

xxviii Neil McLynn, Neil, "Genere Hispanus: Theodosius, Spain and Nicene Orthodoxy", in Hispania in Late Antiquity: Current Perspectives, ed. Kim Bowes and Michael Kulikowski (Leiden: Brill, 2005), 77-120.

${ }^{x x i x}$ Kulikowski, Late Roman Spain, 156-161 discusses the resistance of members of the Theodosian family in Spain to the regime that the usurper Constantine III set up in southern Gaul in the early 400s.

${ }^{x x x}$ On the Rhine crossing, see: Peter Heather, "Why Did the Barbarian Cross the Rhine?", Journal of Late Antiquity 2 (2009): 3-29.

xxxi Hagith Sivan, "An Unedited Letter of the Emperor Honorius to the Spanish Soldiers", Zeitschrift für Papyrologie und Epigraphik 61 (1985): 273-285; Michael Kulikowski, "The 'Epistula Honorii', Again". Zeitschrift für Papyrologie und Epigraphik 122 (1998): 247-252.

xxxii Kulikowski, Late Roman Spain, 186-192.

xxxiii Kulikowski, Late Roman Spain, 197-214, 256-309.

${ }^{\text {xxiv }}$ For edition and translation, see: Richard W. Burgess, The Chronicle of Hydatius and the Consularia Constantinopolitana: two contemporary accounts of the final years of the Roman Empire (Oxford: Clarendon Press, 1993); for studies, see: Carmen Cardelle de Hartmann, Philologische Studien zur Chronik des Hydatius von Chaves (Stuttgart: Steiner, 1994); Steven Muhlberger, The fifth-century chroniclers: Prosper, Hydatius, and the Gallic Chronicler of 452 (Leeds: Francis Cairns, 1990); Josep Vilella, “Idacio, un cronista de su tiempo”, Compostellanum 44 (1999): $39-54$.

${ }^{x x x v}$ Richard W. Burgess, "Hydatius and the Final Frontier: The Fall of the Roman Empire and the End of the World", in Shifting Frontiers in Late Antiquity, ed. Ralph W. Mathisen and Hagith S. Sivan (London: Variorum, 1996), $321-332$.

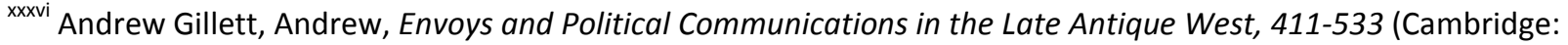
Cambridge University Press, 2003), 36-83.

xxxvii The classic study is Peter Brown, "The Rise and Function of the Holy Man in Late Antiquity", Journal of Roman Studies 61 (1971): 80-101; more recently, see: Claudia Rapp, Holy Bishops in Late Antiquity: The Nature of Christian Leadership in an Age of Transition (Berkeley: University of California Press, 2005); Andrew Fear, José Fernández Urbiña and Mar Marcos, eds., The Role of the Bishop in Late Antiquity: Conflict and Compromise (London: Bloomsbury, 2013).

xxxviii E. A. Thompson, "The End of Roman Spain. Part II", Nottingham Medieval Studies 21 (1977): 3-31.

${ }^{x x x i x}$ Hydatius, Chronicle, 17, ed. Burgess, The Chronicle of Hydatius, 82-83: Subuersis memorata plagarum crassatione Hispaniae prouinciis barbari ad pacem ineundam domino miserante conuersi, sorte ad inhabitandum sibi prouinciarum diuidit regiones. Calliciam Vandali occupant et Suaeui sitam in extremitate Oceani maris occidua. Alani Lusitaniam et Carthaginiansem prouinciae et Vandali cognomine Silingi Beticam sortiuntur.

${ }^{x l}$ Wilhelm Reinhart, Historia General del Reino Hispanico de los Suevos (Madrid: Publicaciones del Seminario de Historia Primitiva del Hombre, 1952); P. C. Díaz, El reino suevo (411-585) (Madrid: Akal, 2011).

xli Francisco Marco Simón, “Hommes et images: rapports entre la Gaule et la Tarraconensis entre le s. II avant J.C. et le s. IV après J.C.", in Hispania et Gallia, ed. Pons Pujol, 79-91.

xlii José Maria Blázquez Martínez, "Relaciones entre Hispania y Galia en la Tardia Antigüedad. Siglos IV y V", in Hispania et Gallia, ed. Pons Pujol, 177-191; Edward James, "Septimania and its Frontier: An Archaeological Approach", in Visigothic Spain: New Approaches, ed. Edward James (Oxford: Clarendon, 1980), 223-241.

xliii Blázquez Martínez, “Relaciones entre Hispania y Galia”, 177-191.

xliv Virginia Burrus, The Making of a Heretic: Gender, Authority, and the Priscillianist Controversy (Berkeley: University of California Press, 1995); H. Chadwick, Priscillian of Avila: the Occult and the Charismatic in the Early Church (Oxford: Clarendon, 1976). 
${ }^{x l v}$ The literature on this topic is voluminous, see, for example: E. A. Thompson, "The Settlement of the Barbarians in Southern Gaul", Journal of Roman Studies 46 (1956): 65-75; Hervig Wolfram, "The Goths in Aquitaine", German Studies Review 2 (1979): 153-168; Hagith Sivan, “On Foederati, Hospitalitas, and the Settlement of the Goths in A.D. 418', The American Journal of Philology 108 (1987): 759-772; Vincent Burns, "The Visigothic Settlement in Aquitania: Imperial Motives", Historia: Zeitschrift für Alte Geschichte 41 (1992), pp. 362-373; Michael Kulikowski, "The Visigothic Settlement in Aquitania: The Imperial Perspective", in Society and Culture in Late Antique Gaul: Revisiting the Sources, eds. Ralph W. Mathisen and Danuta Shanzer (Aldershot: Ashgate, 2001), 26-38. For the hypothesis that the Visigoths were granted tax revenues, which is not widely accepted, see Walter Goffart, Barbarians and Romans A.D. 418-584: the techniques of accommodation (Princeton: Princeton University Press, 1980).

xlvi Isidore of Seville, Historia Gothorum 45, ed. C. Rodríguez Alonso, Las historias de los godos, vándalos y suevos de Isidoro de Sevilla (Léon: Centro de Estudios e Investigagión San Isidoro, 1975), 246-248.

xlvii Contra G. Ripoll, "Sedes regiae en la Hispania de la Antiguedad tardía”, in Sedes Regiae, eds. G. Ripoll and J. M. Gurt (ann. 400-800) (Barcelona: Reial Acadèmia de Bones Lletres, 2000), 371-401.

xlviii Arce, El último siglo, 31-62; Kulikowski, Late Roman Spain, 71-76, 272.

xlix Procopius, History of the Wars, III.xxiv.7-18; IV.iv.33-6, VI.xxx.11-15, trans. Dewing, II, pp. 196-98, 244, IV, pp. 140142; Isidore, Historia Gothorum 22, ed. Rodríguez Alonso, 206-8.

I'Isidore, Historia Gothorum 42, ed. Rodríguez Alonso, 242.

li Céline Martin, La géographie du pouvoir dans l’Espagne visigothique (Lille: Septentrion, 2003), 285.

lii For history of the province see M. Vallejo Girvés, Bizancio y la España tardo antigua (Ss. V-VIII): Un capítulo de historia mediterránea (Alcalá de Henares: Universidad de Alcalá de Henares, 1993); L. A. García Moreno, "The Creation of Byzantium's Spanish province. Causes and propaganda", Byzantion 66 (1996): 101-119; Jamie Wood, "Defending Byzantine Spain: Frontiers and Diplomacy", Early Medieval Europe 18 (2010): 292-319. See, most recently, M. Vallejo Girvés, Hispania y Bizancio: Una relación desconocida (Madrid: Akal, 2012).

liii M. Vallejo Girvés, 'Byzantine Spain and the African Exarchate: An administrative perspective', Jahrbuch der österreichischen Byzantinistik 49 (1999): 13-23.

liv For acceptance of the idea that there was an organised frontier, see: L. A. García Moreno, “Organización militar de Bizancio en la península ibérica (ss. VI-VII)”, Hispania 33 (1973): 5-22; L. A. García Moreno, “Estudios sobre la organisación administrativa del Reino Visigodo de Toledo", Anuario de historia del Derecho Español 44 (1974): 5-157. For criticisms, see: G. Ripoll Lopez, "On the supposed frontier between the regnum Visigothorum and Byzantine Hispania", in The Transformation of frontiers from Late Antiquity to the Carolingians, eds. W. Pohl, I. Wood and $\mathrm{H}$. Reimitz (Leiden: Brill, 2000), 99, 107-9, 115.

Iv A. González Blanco, "Romanidad y Bizantinismo en el sudests Hispano durante la Antigüedad Tardía”, in Spania: estudis d'antiguitat tardana oferts en homenatge al profesor Pere de Palol i Salellas (Barcelona: Abadia de Montserrat, 1996), 133.

Ivi For a cautious 'middle path' regarding frontier relations between the Byzantines and the Visigoths, see Wood, "Defending Byzantine Spain".

Ivii Martin, La géographie du pouvoir, 287; cf. Wood, “Defending Byzantine Spain", 307-309 for the concept of "zones of interaction".

Iviii See Jaime Vizcaíno Sánchez, La presencia bizantina en Hispania (siglos VI-VII). La documentación arqueológica (Murcia: Universidad de Murcia, 2009) for a comprehensive survey of the archaeological evidence for Byzantine presence in and influence on Spain in sixth and seventh centuries; L. A. García Moreno, "Colonias de comerciantes orientales en la Península Ibérica. S. V-VII", Habis 3 (1972): 127-154 for epigraphic evidence for eastern merchants in Spain; Enrique García Vargas, “Oriental trade in the Iberian Peninsula during Late Antiquity (4th-7th centuries AD): An Archaeological Perspective”, in David Hernández de la Fuente, ed., New Perspectives on Late Antiquity (Newcastle: Cambridge Scholars Publishing, 2011), 76-117 for material evidence for trade in many kinds of goods. 
lix Paul Reynolds (1993), Settlement and Pottery in the Vinalopó Valley (Alicante, Spain) A.D. 400-700 (Oxford: Tempus Reparatum, 1993), 39; Paul Reynolds, 'Hispania in the Late Roman Mediterranean: Ceramics and Trade', in Hispania in late antiquity, eds. Bowes and Kulikowski, 369-486; Reynolds, Hispania, 120-130.

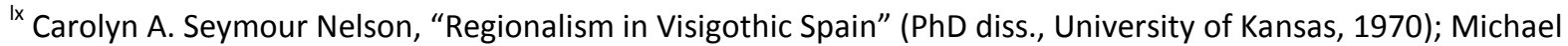
Kulikowski, "The Interdependence of Town and Country in Late Antique Spain", in Urban Centers and Rural Contexts in Late Antiquity, eds. Thomas S. Burns and John W. Eadie (East Lansing: Michigan State University Press, 2001), 149, 156; Kulikowski, Late Roman Spain, 256-86.

Ixi Reynolds, Hispania, 120-135; Juan Antonio Quirós Castillo, "Early medieval landscapes in north-west Spain: local powers and communities, fifth-tenth centuries", Early Medieval Europe 19 (2011): 289-309.

Ixii K. E. Carr, Vandals to Visigoths. Rural Settlement Patterns in Early Medieval Spain (Ann Arbor: University of Michigan Press, 2002), 200-202.

Ixiii Roger Collins, Visigothic Spain, 409-711 (Oxford: Blackwell, 2004), 207-210. See T. Lewit, T., "Vanishing villas: what happened to élite rural habitations in the west in the $5^{\text {th }}-6^{\text {th }}$ centuries AD?", Journal of Roman Archaeology 16 (2003): 260-274 for suggestion that some villa sites remained occupied to a much later date than has previously been suggested. See also: Kim Bowes and A. Gutteridge, "Rethinking the later Roman landscape", Journal of Roman Archaeology 18 (2005): 405-418; Alexandra Chavarría Arnau, "Villas in Hispania During the Fourth and Fifth Centuries", in Hispania in late antiquity, eds. Bowes and Kulikowski, 519-555.

Ixiv Martin, La géographie du pouvoir, 82-98.

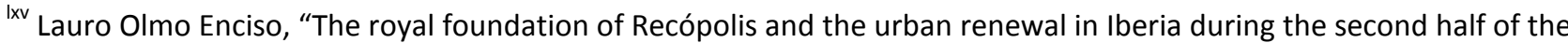
sixth century", in Post-Roman Towns, Trade and Settlement in Europe and Byzantium, Vol. 1. The Heirs of the Roman West, ed. Joachim Henning (Berlin: Walter de Gruyter, 2007), 181-196; G. Ripoll, "Changes in the topography of power: from ciuitates to sedes regiae in Hispania", in The Construction of Communities in the Early Middle Ages. Texts, Resources and Artefacts, eds. R. Corradini, M. Diesenberger and H. Reimitz (Leiden: Brill, 2003), 123-148.

Ixvi Martin, La géographie du pouvoir, 143-203.

Ixvii Santiago Castellanos, "The Political Nature of Taxation in Visigothic Spain”, Early Medieval Europe 12 (2003): $201-$ 228; Santiago Castellanos and Iñaki Martín Viso, "The local articulation of central power in the north of the Iberian Peninsula (500-1000)", Early Medieval Europe 13 (2005): 1-42.

Ixviii Maria R. Valverde Castro, Ideología, simbolismo y ejercicio del poder real en la monarquía visigoda: un proceso de cambio (Salamanca: Ediciones Universidad de Salamanca, 2000); Jamie Wood, The Politics of Identity in Visigothic Spain: Religion and Power in the Histories of Isidore of Seville (Leiden: Brill, 2012); Joaquín Martínez Pizarro, The Story of Wamba. Julian of Toledo's Historia Wambae Regis (Washington: Catholic University of America Press, 2005); Michael McCormick, Eternal Victory: Triumphal rulership in late antiquity, Byzantium and the early medieval West (Cambridge: Cambridge University Press, 1986), 315-327.

Ixix Pablo C. Díaz, "City and Territory in Hispania in Late Antiquity", in Towns and Their Territories Between Late Antiquity and the Early Middles Ages, eds. Gian Pietro Brogiolo, Nancy Gauthier, Neil Christie (Leiden: Brill, 2000), 3-35.

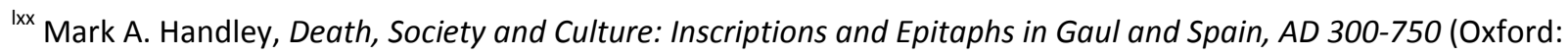
Archaeopress, 2003).

Ixxi E. A. Thompson, "The Conversion of the Visigoths to Catholicism", Nottingham Medieval Studies 4 (1960): 4-35; Jocelyn N. Hillgarth, "Coins and Chronicles: Propaganda in Sixth-Century Spain and the Byzantine Background", Historia 15 (1966): 483-508; Roger Collins, “¿Dónde estaban los arrianos en el año 589?”, in Actas del XIV Centenario del III Concilio de Toledo (589-1989) (Toledo: Arzobispado de Toledo, 1991), 1-12.

Ixxii Pedro-Ruiz Torres, "Political Uses of History in Spain", Mediterranean Historical Review 16 (2001): 95-116; Xenia Bonch-Bruevich, "Ideologies of the Spanish Reconquest and Isidore's Political Thought", Mediterranean Studies 17 (2008): 27-45. 
Ixxiii Rachel L. Stocking, "Review article: Continuity, culture and the state in late antique and early medieval Iberia," Early Medieval Europe 15 (2007): 335-348; Santiago Castellanos, Los godos y la cruz: Recaredo y la unidad de Spania (Madrid: Alianza, 2007), 315-339.

Ixxiv F. X. Murphy, "St Julian of Toledo and the Fall of Visigothic Kingdom in Spain", Speculum (1957): 1-27; Collins, Visigothic Spain, 38-143.

${ }^{\text {Ixxv }}$ Roger Collins, The Arab Conquest of Spain, 710-797 (Oxford: Basil Blackwell, 1989); Collins, Visigothic Spain, 117-143; Nicola Clarke, The Muslim Conquest of Iberia: Medieval Arabic Narratives (Abingdon: Routledge, 2012).

Ixxvi For example, the metropolitan see of Baetica was Seville, whereas the capital of the late Roman province was Córdoba.

Ixxvii William E. Kilngshirn, Caesarius of Arles: The Making of a Christian Community in Late Antique Gaul (Cambridge: Cambridge University Press, 1994), 131-132.

Ixxviii Rachel L. Stocking, Bishops, Councils and Consensus in the Visigothic Kingdom, 589-633 (Ann Arbor: The University of Michigan Press, 2000), 96-99, 108-109.

${ }^{\text {Ixxix }}$ A. González Blanco, "El decreto de Gundemaro y la historia del siglo VII," in Los Visigodos: Historia y Civilización, ed. A. González Blanco (Murcia: Universidad de Murcia, 1986), 159-169; Jamie Wood, "Playing the Fame Game: Bibliography, Celebrity and Primacy in Late Antique Spain", Journal of Early Christian Studies 20 (2012): 613-640.

${ }^{\text {Ixxx }}$ L. S. B. MacCoull, "Isidore and the Akephaloi", Greek, Roman and Byzantine Studies 39 (1998): 169-178.

Ixxxi Wood, "Defending Byzantine Spain".

Ixxxii Wood, Politics of Identity.

Ixxiii Martínez Pizarro, The Story of Wamba.

Ixxiv Frank Reiss, Narbonne and its Territory in Late Antiquity: From the Visigoths to the Arabs (Farnham: Ashgate, 2013), 131-220.

Ixxxv Walter Goffart, "Byzantine Policy in the West under Tiberius II and Maurice: the Pretenders Hermengild and Gundovald," Traditio 13 (1957): 85-118.

Ixxxvi Stocking, Bishops, 96-98, 108-109 suggests that the Council of Narbonne (589) was, in part, a reaction to the rebellion of the previous year.

Ixxxvii Víctor Lluís Pérez Garcia, "Late Roman and Visigothic military fortifications in Tarraconensis - border defence system", Aquila Legionis 15 (2012): 165-202. See also: James, "Septimania and its Frontier".

Ixxxviii George C. Miles, The Coinage of the Visigoths of Spain, Leovigild to Achila II (New York: American Numismatic Society, 1952), 444-446.

Ixxxix Sam Koon and Jamie Wood, "Unity from Disunity: Law, Rhetoric and Power in the Visigothic Kingdom", European Review of History 16 (2009): 793-808; P. D. King, Law and Society in the Visigothic Kingdom (Cambridge: Cambridge University Press, 1972).

${ }^{x c}$ Castellanos, "The Political Nature of Taxation"; Castellanos and Martín Viso, "The local articulation of central power".

${ }^{x c i}$ Wood, Politics of Identity.

xcii C.f. Greg Woolf, Becoming Roman: The Origins of Provincial Civilization in Gaul (Cambridge: Cambridge University Press, 2000). 